JAMP: Jurnal Adminitrasi dan Manajemen Pendidikan

Volume 4 Nomor 4 Desember 2021, Hal : 358 - 363

Tersedia Online di http://journal2.um.ac.id/index.php/jamp/

ISSN 2615-8574 (online)

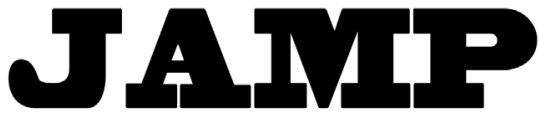

JURNAL ADMINISTRASI DAN MANAJEMEN PENDIDIKAN

\title{
PERSEPSI GURU TENTANG KEPEMIMPINAN KEPALA SEKOLAH DASAR NEGERI
}

\author{
Rini Syevyilni Wisda \\ Institut Agama Islam Negeri Kerinci, Jln. Kapten Muradi Sungai Liuk Pesisir Bukit Kota Sungai Penuh \\ email: wisdarini@gmail.com (082384984704)
}

\begin{abstract}
The background of this research is the leadership of the principal of the State Elementary School Sub-district in carrying out its functions, it is not carried out properly. This study aims to determine the teacher's perception of the principal's leadership in terms of influencing, motivating, moving, and directing. This research method is quantitative. Collecting data using a questionnaire. The sample of this research is teachers of State elemntary School as many as 51 people. The results showed that in general it can be said that the leadership of the principal of the State Elementary School is good with an average percentage of $64.01 \%$ of respondents stating always and often.
\end{abstract}

Keywords: Teachers Perception; Principal Leadership

\begin{abstract}
Abstrak: Penelitian ini dilatarbelakangi oleh kepemimpinan kepala sekolah Dasar Negeri dalam melaksanakan fungsinya kurang terlaksana sebagaimana mestinya. Penelitian Ini bertujuan untuk mengetahui persepsi guru tentang kepemimpinan kepala sekolah dilihat dari aspek mempengaruhi, memotivasi, menggerakkan, dan mengarahkan. Penelitian ini menggunakan metode Kuantitatif. Pengumpulan data dengan menggunakan angket, Sampel dalam penelitian ini guru SD Sebanyak 51 orang. Hasil Penelitian menunjukkan bahwa secara umum dapat dikatakan bahwa kepemimpinan kepala sekolah Dasar Negeri baik dengan persentase Rata-rata 64,01\% responden menyatakan selalu dan sering.
\end{abstract}

Kata Kunci: Persepsi Guru; Kepemimpinan Kepala Sekolah

persepsi merupakan sebuah penilaian, pandangan, anggapan yang diberikan seseorang terhadap suatu hal yang mereka lihat, banyak hal yang bisa menjadi faktor adanya persepsi seseorang terhadap suatu hal, penilaian dari persepsi ini bersifat relatif sesuai dengan orang dan hal yang dilihatnya. Persepsi diberikan oleh siapa saja dimana saja terhadap hal apa saja dalam organisasi. Suatu organisasi umum maupun organisasi sekolah persepsi diberikan oleh bawahan, guru guna untuk mengevaluasi bagaimana kinerja kepemimpinan selama ini dalam memimpin, melaksanakan kegiatan, program dan tujuan yang telah ditetapkan. Sesuai dengan pendapat Robbins dan Judge Persepi merupakan suatu proses seseorang mengorganisasikan dan mengintepretasikan kesan sensoris untuk memberikan pengertian pada lingkungannya (Robbins dan Judge, 2015:103). Suwarto (2010:53) menyatakan bahwa persepsi mencakup penafsiran objek, tanda dan orang dari sudut pengalaman yang bersangkutan, atau persepsi mencakup penerimaan stimulus, pengorganisasian stimulus dan penerjemahan.penafsiran stimulus yang telah diroganisasi dengan cara yang dapat mempengaruhi perilaku dan membentuk sikap.

Gilmer dalam Hapsari (2004:69) menyatakan bahwa persepsi dipengaruhi oleh berbagai faktor, antara lain faktor belajar, motivasi, dan pemerhati perseptor atau pemersepsi ketika proses persepsi terjadi. Adanya beberapa faktor bersifat subyektif yang mempengaruhinya, maka kesan yang diperoleh masing-masing individu akan berbeda satu sama lain. Persepsi dikenal juga dengan pandangan yang dimerupakan mutlak ada pada setiap orang terhadap sesuatu hal baik itu yang sudah lama berinteraksi maupun baru mereka lihat. Sekolah merupakan sebuah wadah organisasi memiliki pemimpin dan tujuan yaitu tujuan pendidikan. Mencapai tujuan pendidikan diperlukan suatu dukungan motivasi, arahan, pengaruh dari pemimpin dari hal tersebut yang tidak luput sebuah persepsi 
Studi pendahuluan yang telah dilaksanakan pada guru-guru SD Negeri dapat diketahui bahwasannya persepsi guru terhadap kepemimpinan kepala sekolah masing-masing sudah baik. Sebagian besar kepala sekolah dalam melaksanakan tugasnya sudah sesuai dengan fungsi dari kepemimpinannya, kepala sekolah tidak memperlihatkan statusnya kepala sekolah, melainkan menganggap bawahan atau gurugurunya sebagai rekan kerja, bekerja secara bersama untuk mencapai tujuan yang telah ditetapkan. Sifat Kepemimpinan yang dimiliki oleh kepala sekolah membina hubungan antar individu, untuk menggunakan wewenang dan kemampuan untuk menggerakkan, mempengaruhi, dan mengarahkan bawahan atau guru dalam mencapai tujuan yang ditetapkan.

Pengelolaan sekolah seharusnya dipimpin oleh seorang kepala sekolah yang mempunyai kemampuan yang memadai untuk memimpin, karena keberhasilan suatu pendidikan di sekolah sangat ditentukan oleh gaya kepemimpinan kepala sekolah dengan motor penggerak aktivitas yang ada dalam mencapai tujuan. Yulk (2004:3) mengartikan secara umum kepemimpinan merupakan proses mempengaruhi pengikut, bawahan pengorganisasian dari kegiatan-kegiatan kerja untuk mencapai tujuan yang ditetapkan, proses memotivasi bawahan untuk mencapai tujuan, pemeliharaan hubungan, kerjasama dan team work, serta membangun dan mendapatkan dukungan kerjasama baik dari dalam maupun dari luar.

\section{METODE}

Penelitian menggunakan pendekatan Kuantitatif dengan jenis penelitian kuantitatif deskriptif . Karena penelitian ini tertuju pada pengungkapan masalah yang terjadi pada masa sekarang. Penelitian kuantitatif memiliki sifat umum yaitu tujuan, pendekatan, subjek, sumber data sudah mantap dan rinci sejak awal hal ini menyebabkan penelitian dapat lebih terarah sesuai dengan rencana (Arikunto. S 2006:13). Lokasi penelitian yang dipilih untuk melaksanakan penelitian yaitu SD. Populasi penelitian ini adalah Seluruh guru Sekolah Dasar berjumlah 102 orang. Sampel pada penelitian ini berjumlah 51 orang guru. Pengumpulan data pada penelitian ini menggunakan instrument penelitian dengan angket menggunakan skala likert. pada pengukuran setiap indicator variabel dengan 5 (lima) alternative jawaban yaitu: Selalu (SL), Sering (SR), Kadang-kadang (KDG), Jarang (JR), dan tidak Pernah (TP). Analisis data yang digunakan terdiri dari menghitung korelasi, Mencari persentase dan menentukan gambaran secara kualitatif hasil penelitian persepsi guru terhadap kepemimpinan kepala sekolah.

\section{HASIL}

\section{Analisis Deskripsi Data}

\section{Persepsi Guru Tentang Kepemimpinan Kepala Sekolah dalam Mempengaruhi Bawahan di Sekolah Dasar}

Hasil pengeolahan data persepsi guru tentang kepemimpinan kepala sekolah dalam mempengaruhi bawahan di Sekolah Dasar dapat dilihat pada tabel di bawah ini setelah dihitung persentase frekuensi.

Tabel 1. Rekapitulasi Persepsi Guru Tentang Kepemimpinan Kepala Sekolah Dasar dalam Mempengaruhi Bawahan

\begin{tabular}{lllllll}
\hline \multirow{2}{*}{ No } & \multirow{2}{*}{ Indikator Mempengaruhi } & \multicolumn{5}{c}{ Rata-rata Alternatif Jawaban responden } \\
& & SL & SR & KDG & JR & TP \\
\hline 1 & $\begin{array}{l}\text { Memberikan pelayanan dengan baik } \\
\text { dan sabar }\end{array}$ & 33,33 & 26,47 & 11,76 & 13,73 & 14,71 \\
2 & Membantu dan Memenuhi janji & 35,29 & 34,31 & 17,65 & 9,8 & 2,93 \\
3 & Memahami dan menghargai & 30,39 & 42,16 & 9,8 & 8,82 & 8,82 \\
4 & Memberitahukan dan mengambil & 31,37 & 36,27 & 9,8 & 14,71 & 7,84 \\
& inisiatif & & & & & \\
5 & Mengakui dan merespon & 33,33 & 32,35 & 14,71 & 11,76 & 7.84 \\
6 & Memperhatikan dan memperbaharui & 34,31 & 24,51 & 12,75 & 12,75 & 15,69
\end{tabular}




\begin{tabular}{lllllll}
\hline \multirow{2}{*}{ No } & \multirow{2}{*}{ Indikator Mempengaruhi } & \multicolumn{5}{c}{ Rata-rata Alternatif Jawaban responden } \\
& & SL & SR & KDG & JR & TP \\
\hline 7 & Menerima dan menyampaikan & 33,33 & 32,35 & 14,71 & 11,76 & 7,84 \\
8 & $\begin{array}{l}\text { Menyediakan waktu dan membantu } \\
\text { bawahan }\end{array}$ & 28,43 & 18.63 & 34,31 & 11,76 & 9,82 \\
9 & & & & & \\
\multirow{2}{*}{$\begin{array}{l}\text { Menggunakan Bahasa dan melibatkan } \\
\text { bawahan }\end{array}$} & 34,31 & 24,51 & 12,75 & 12,75 & 15,69 \\
10 & & & & & \\
& Membimbing dan membuat aturan & 39,22 & 24,51 & 12,75 & 12,75 & 10,78 \\
& Rata-rata & $\mathbf{3 2}$ & $\mathbf{3 4 , 0 9}$ & $\mathbf{1 2 , 0 8}$ & $\mathbf{9 , 6 9}$ & $\mathbf{1 2 , 1 5}$ \\
\hline
\end{tabular}

Berdasarkan tabel 1 di atas dapat dilihat, rata-rata 66,09\% guru menyatakan kepala Sekolah Dasar selalu dan sering mempengaruhi bawahan, 12,08 \% guru menyatakan kadang-kadang dan 21,84\% guru menyatakan jarang dan tidak pernah. Dengan demikian dapat dikatakan bahwa kepemimpinan kepala Sekolah Dasar telah mempengaruhi bawahannya dengan baik.

\section{Persepsi Guru Tentang Kepemimpinan Kepala Sekolah dalam Memotivasi Bawahan di Sekolah Dasar}

Hasil dari pengelolahan data persepsi guru tentang kepemimpinan kepala sekolah dalam memotivasi bawahan di Sekolah Dasar dapat dilihat pada table 2 di bawah ini.

Tabel 2. Rekapitulasi Persepsi Guru Tentang Kepemimpinan Kepala Sekolah Dasar dalam Memotivasi Bawahan

\begin{tabular}{lllllll}
\hline \multirow{2}{*}{ No Indikator Memotivasi } & \multicolumn{5}{c}{ Rata-Rata Alternatif Jawaban Responden } \\
& SL & SR & KDG & JR & TP \\
\hline 1 & Memberikan Pujian dan Penghargaan & 33.33 & 20,59 & 20.59 & 17,65 & 7,84 \\
2 & Memberikan Kepercayaan & 35,29 & 34,31 & 17,65 & 9,8 & 2,93 \\
3 & Memberikan Kesempatan & 30,39 & 42,16 & 9,8 & 8,82 & 8,82 \\
& Mengemukakan ide-ide & & & & & \\
4 & Memberikan insentif dan Imbalan & 31,37 & 36,27 & 9,8 & 17,71 & 7,84 \\
5 & Menjalinkan hubungan yang harmonis & 33,33 & 32,35 & 14,71 & 11,76 & 7,84 \\
6 & Memberikan petunjuk dan nasehat & 28,34 & 18,63 & 34,31 & 11,76 & 6,8 \\
7 & Memberikan teguran dan sanksi-sanksi & 33,333 & 32,35 & 14,71 & 11,76 & 7,84 \\
8 & Menyediakan peralatan dan bahan & 28,43 & 19,63 & 34,31 & 11,76 & 6,82 \\
9 & Memberikan pelayanan & 34,31 & 24,51 & 12,75 & 12,75 & 15,69 \\
10 & Memberikan kesempatan & 42,16 & 25,49 & 10,78 & 10,78 & 1078 \\
& meningkatkan penegtahuan & & & & & \\
& Rata-Rata & 33,03 & 28,63 & 17,94 & 12,46 & 11,5 \\
\hline
\end{tabular}

Berdasarkan tabel 2 di atas dapat dilihat, rata-rata 61,66\% guru menyatakan Kepala Sekolah Dasar selalu dan sering memmotivasi bawahan 17,94\% guru menyatakan kadang-kadang dan 23,96\% guru menyatakan jarang dan tidak pernah, Dengan demikian dapat dikatakan bahwa kepemimpinan kepala Sekolah Dasar telah memotivasi bawahannya dengan baik .

\section{Persepsi Guru Tentang Kepemimpinan Kepala Sekolah Dalam Menggerakkan Bawahan di Sekolah Dasar}

Hasil Pengelolahan data persepsi guru tentang kepemimpinan kepela sekolah dalam menggerakkan bawahan di Sekolah Dasar dapat dilihat pada tabel berikut ini.

Tabel 3. Persepsi Guru Tentang kepemimpinan Kepala Sekolah Dasar dalam Menggerakkan Bawahan

\begin{tabular}{lllllll}
\hline \multirow{2}{*}{ No Indikator Menggerakkan Bawahan } & \multirow{2}{*}{ Rata-rata Alternatif Jawaban Responden } \\
& & SL & SR & KDG & JR & TP \\
\hline 1 & Memberikan penghargaan & 35,29 & 34,31 & 17,65 & 9,8 & 2,93 \\
2 & Melakukan Pengembangan & 31,37 & 36,27 & 9,8 & 14,71 & 7,84
\end{tabular}




\begin{tabular}{lllllll}
\hline \multirow{2}{*}{ No Indikator Menggerakkan Bawahan } & \multicolumn{5}{c}{ Rata-rata Alternatif Jawaban Responden } \\
& & SL & SR & KDG & JR & TP \\
\hline 3 & Memberikan Keterlibatan & 33,33 & 32,35 & 14,71 & 11,76 & 7,84 \\
4 & Memberikan Kesempatan Untuk Maju & 33,33 & $32,, 35$ & 14,71 & 11,76 & 7,84 \\
5 & Memberikan Tanggung Jawab & 42,16 & 25,49 & 10,78 & 10,78 & 10,78 \\
& Rata-rata & 35,1 & 32,15 & 13,53 & 11,76 & 7,45 \\
\hline
\end{tabular}

Tabel di atas dapat dilihat rata-rata 67,25\% guru menytakan kepala Sekolah Dasar selalu dan sering menggerakkan bawahan, 13,53\% guru menyatakan kadang-kadang, dan 11,21 \% guru menyatakan jarang dan tidak pernah. Dengan demikian dapat dikatakan bahwa kepemimpinan kepala Sekolah Dasar telah menggerakkan bawahan dengan baik.

\section{Persepsi Guru Tentang Kepemimpinan Kepala Sekolah Dalam mengarahkan Bawahan di Sekolah Dasar}

Hasil pengolahan data persepsi guru tentang kepemimpinan kepala sekolah dalam menggerakkan bawahan di sekolah Dasar dapat dilihat pada tabel berikut ini.

Tabel 4. Persepsi Guru Tentang kepemimpinan Kepala Sekolah Dasar dalam Mengarahkan Bawahan

\begin{tabular}{lllllll}
\hline \multirow{2}{*}{ No } & \multirow{2}{*}{ Indikator Mengarahkan } & \multicolumn{4}{c}{ Rata-rata Alternatif Jawaban Responden } \\
& & SL & SR & KDG & JR & TO \\
\hline 1 & Memberikan penjelasan dan petunjuk & 30,39 & 42,16 & 9,8 & 8,82 & 8,82 \\
2 & Memberikan gambaran & 33,33 & 32,35 & 14,71 & 11,76 & 7,84 \\
3 & Membangkitkan dan membina & 34.31 & 24,51 & 12,75 & 12,76 & 15,69 \\
4 & Memberikan dan Membimbing & 28,43 & 18,63 & 34,31 & 11,76 & 6,82 \\
& Rata-rata & 31,62 & 29,41 & 17,89 & 11,28 & 9,79 \\
\hline
\end{tabular}

Sesuai tabel di atas dapat dilihat rata-rata 61,03 guru menyatakan Kepala Sekolah Dasar selalu dan sering mengarahkan bawahan 17,89\% guru menyatakan Kadang-kadang dan 22,07\% guru menyatakan jarang dan tidak pernah. Dengan demikian dapat dikatakan bahwa kepemimpina kepala sekolah Dasar telah mengarahkan bawahan dengan cukup baik.

Berdasarkan uraian-uraian pada tabel 1, tabel 2 dan tabel 3 di atas dapat dilihat persepsi guru tentang kepemimpinan Kepala Sekolah Dasar dapat dilihat pada tabel 5 berikut ini:

Tabel 5. Rekapitulasi Persepsi Guru Tentang Kepemimpinan Kepala Sekolah Dasar

\begin{tabular}{lllllll}
\hline \multirow{2}{*}{ No } & \multirow{2}{*}{ Aspek kepemimpinan } & \multicolumn{5}{l}{ Rata-rata Alternatif Jawaban Responden } \\
& & SL & SR & KDG & JR & TP \\
\hline 1 & Mempengaruhi & 32 & 34,09 & 12,08 & 9,69 & 12,15 \\
2 & Memotivasi & 33,03 & 28,63 & 17,94 & 12,46 & 11,5 \\
3 & Menggerakkan & 35,01 & 32,15 & 13,53 & 11,76 & 7,45 \\
4 & Mengarahkan & 31,62 & 29,41 & 17,89 & 11,28 & 9,79 \\
& Rata-rata & 32,94 & 31,07 & 15,36 & 11,3 & 10,2 \\
\hline
\end{tabular}

Dari tabel di atas dapat dilihat, rata-rata 64,015 guru menyatakan Kepala Sekolah Dasar selalu dan sering memmepngaruhi, memotivasi, menggerakkan dan mengarahkan bawahannya, 13,53 guru menyatakan kadang-kadang, dan 11,21\% guru menyatakan jarang dan tidak pernah. Hal demikian dapat dikatakan bahwa kepemimpinan kepala Sekolah Dasar telah cukup baik.

\section{PEMBAHASAN}

\section{Persepsi Guru Tentang Kepemimpinan Kepala Sekolah dalam Mempengaruhi Bawahan di Sekolah Dasar}

Hasil penelitian di atas tentang persepsi Guru terhadap kepemimpinan kepala sekolah dalam mempengaruhi bawahan di sekolah Dasar sudah baik dengan hasil 66,09\% guru menyatakan selalu. 
Hasil ini menunjukkan bahwa kepala sekolah dalam kepemimpinan telah mampu mempngaruhi guru untuk dapat bekerja dan melaksanakan tugsa pokonya dengan baik.

Bagusnya Kepemimpinan kepala sekolah terlihat dari caranya dalam mempengaruhi, guru, staf, orang tua siswa, bawahannya dan pihak-pihak yang terkait untuk bekerja sesuai dengan tujuan, guna mencapai mencapai tujuan Pendidikan. sejalan dengan pendapat Sutisna menjelaskan kepemimpinan merupakan suatu "proses mempengaruhi kegiatan seseorang atau kelompok dalam usaha kearah pencapai tujuan dalam situasi tertentu. Dijelaskan juga oleh Nawawi kepemimpinan merupakan suatu tindakan yeng bertujuan untuk mempengaruhi perilaku bawahan agar bekerja secara bersama untuk mencapai tujuan yang telah ditetapkan secara bersama. Sesuai dengan pendapat Daryanto Bahwa kepemimpinan merupakan suatu proses mempengaruhi kegiatan-kegiatan suatu kelompok yang ada pada organisasi untuk mencapai tujuan yang di tetapkan (Daryanto: 2011). Kepala sekolah adalah orang yang mempunyai peranan yang sangat penting, penggerak, untuk mencapai tujuan sekolah.

\section{Persepsi Guru Tentang Kepemimpinan Kepala Sekolah dalam Memotivasi Bawahan di Sekolah Dasar}

Hasil penelitian di atas tentang persepsi Guru terhadap kepemimpinan kepala sekolah dalam memotivasi bawahan di sekolah Dasar sudah baik dengan hasil rata 61,66\% guru menyatakan Kepala Sekolah Dasar selalu. hasil ini menunjukkan bahwa kepala sekolah dalam kepemimpinan telah mampu memotivasi guru untuk dapat bekerja dan melaksanakan tugsa pokonya dengan baik.

Berjalannya program kegiatan di sekolah tidak terlepas dari motivasi dan dorongan yang diberikan oleh seorang kepala sekolah untuk guru atau bawahannya, baik sesecara lansung maupun tidak lansung. Dijelaskan juga oleh Suparlan bahwa ada beberapa tugas yang dilaksanakan oleh seorang kepala sekolah dalam menjalankan tugasnya yaitu EMASLIMDEF (educator, manager, administrator, supervisor, leader, innovator, motivator, dinamisator, Evaluator, dan facililtator. (Suparlan:2006). Berdasrkan data di atas tersebut bahwa kepala sekolah telah memberikan motivasi kepada bawahnnya dalam menjelankan tugas sebagai guru dan pendidik dengan adanya motivasi ataupun dorongan yang diberikan kepala sekolah kepada guru akan meningkatkan kinerja guru yang lebih bagus, Meningkatnya mutu pendidikan harus tidak terlepas dari pembaharuan dan dorongan semua elemen yang ada di sekolah untuk mencapai tujuan yang lebih berkualitas

Persepsi Guru Tentang Kepemimpinan Kepala Sekolah Dalam Menggerakkan Bawahan di Sekolah Dasar

Hasil penelitian di atas tentang persepsi Guru terhadap kepemimpinan kepala sekolah dalam memotivasi bawahan di Sekolah Dasar sudah baik dengan hasil rata-rata 67,25\% guru menyatakan Kepala Sekolah Dasar Rayon Kecamatan Ranah Pesisir selalu. Sesuai dengan hasil persentase guru di atas terhadap kepemimpinan kepala sekolah dalam menggerakkan guru dan bawahannya sesuai dengan tujuan yang telah ditetapkan, sejalan dengan hal tersebut dijelaskan oleh Abbas (2014) menjelaskan kepemimpinan merupakan kemampuan untuk menggerakkan segala sumber daya yang ada dalam organisasi, sehingga dapat diberdayakan, didayagunakan secara maksimal,untuk mencapai tujuan yang telah ditetapkan.

Kepala sekolah selaku ujung tombak dalam Mengerakkan guru atau bawahan merupakan hal yang sangat penting karena berkulitasnya pendidikan tidak terlepas dari sebuah penggerakan yang diberikan oleh kepala sekolah kepada guru dalam menjalankan tugasnya. Kepala sekolah merupakan sebagai penggerak dalam melaksnakaan proses pendidikan untuk mencapai tujuan pendidikan yang berkualitas. Kemampuan menggerakkan guru yang diberikan oleh kepala sekolah tidak terlepas dari kemampuan berkomunikasi yang dimiliki oleh seorang pemimpin, bagusnya komunikasi dan bahasa yang digunakan oleh kepala sekolah dalam menggerakkan guru maka pesan dengan mudah diterima dan dipahami oleh guru sehingga apa perintah, tugas bias terlaksana dengan baik.

\section{Persepsi Guru Tentang Kepemimpinan Kepala Sekolah Dalam mengarahkan Bawahan di Sekolah Dasar}

Hasil penelitian di atas tentang persepsi Guru terhadap kepemimpinan kepala sekolah dalam mempengaruhi bawahan di Sekolah Dasar sudah baik dengan hasil 61,03\% guru menyatakan selalu. Kepemimpinan kepala sekolah merupakan suatu kemampuan dan kewenangan untuk mempengaruhi, menggerakkan dan mengarahkan tindakan serta mendorong timbulnya kemauan yang kuat dengan penuh 
semangat dan percaya diri pada diri guru, staf dan siswa dalam melaksanakan tugas masing-masing demi kemajuan dan memberikan inspirasi sekolah dalam mencapai tujuan. Menurut (Mulyasa, 2012) kepala sekolah merupakan salah satu struktur terpenting dalam organisasi kependidikan formal. kepemimpinan kepala sekolah yang baik dapat memberikan dampak positif dan perubahan yang baik dalam sistem pendidikan di sekolah. Bagusnya contoh yang dierikan oleh kepala sekolah dalam memimpin guruguru akan berpengaruh kepada penilaian guru dan juga kinerja guru dalam menjalankan tugasnya untuk mencapai tujuan pendidikan.

\section{SIMPULAN DAN SARAN}

\section{Simpulan}

Hasil dari analisis data penelitian yang telah dilakukan dan pembahasan diperoleh kesimpulan bahwa: 1. Persepsi guru tentang kepemimpinan kepala sekolah dalam mempengaruhi bawahan di Sekolah Dasar berada pada katgori baik hal ini terlihat jelas bahwa kepala sekolah sudah mampu mempengaruhi guru-gurunya dalam melaksnaakn tugas dengan baik. 2. Persepsi guru tentang kepemimpinan kepala sekolah dalam memotivasi bawahan di Sekolah Dasar berada pada kategori baik, dalam memotivasi guru-guru untuk melaksanakn tugas pokoknya proses belajar mengajar di kelas untuk mencapai tujuan pembelajaran. 3. Persepsi guru tentang kepemimpinan kepala sekolah dalam menggerakkan bawahan di Sekolah Dasar berada pada kategori baik dalam menggerakkan guru-guru sesuai dengan kemampuan yang dimiliki oleh masing-masing guru dengan cara membangun komunikasi yang bagus dengan bawahan. 4. Persepsi guru tentang kepemimpinan kepala sekolah dalam mengarahkan bawahan di Sekolah Dasar berda pada kategori baik dalam mengarahkan bawahan untuk melaksanakan tugas dalam mencapai tujuan pendidikan.

\section{Saran}

Saran yang dapat diberikan kepada peneliti selanjutnya: 1. Mahasiswa yang akan melaksanakan penelitian tentang persepsi kepemimpinan kepala sekolah secara mendalam dan terinci agar kepemimpinan kepala sekolah lebih bagus kedepannya. 2. Bagi peneliti selanjutnya diharapkan penelitian mengenai persepsi kepemimpinan kepala sekolah dapat dilaksankan lebih mendalam dan menyeluruh agar penelitiannya lebih luas dan terbaru. dan artikel ini diharapkan bisa dijadikan bahan pembanding untuk penelitian selanjutnya baik bagi peneliti selanjutnya.

\section{DAFTAR RUJUKAN}

Abbas, S. 2014. Manajemen Perguruan Tinggi. Jakarta: Kencana.

Arikunto. S. 2006. Prosedur Penelitian: Suatu Pendekatan Praktek. Jakarta: Rineka Cipta.

Daryanto. 2011. Model Pembelajaran . Bandung: PT Sarana Tutorial Nurani Sejahtera

Gary Yulk. 2004 Kepemimpinan dalam Organisasi, Jakarta: Prenhallindo

Hapsari, Iriani Indri dan Ira Puspitawati, 2004, Psikologi Faal.Bandung : Rosda Karya

Heri Nurranto, Fadjriah Hapsari, Muzdalifah. 2017. Persepsi Guru atas Kepemimpinan Sekolah dan Kesejahteraan Sebagai Prediktor Kinerja Guru: Journal of Applied Business and Economics Vol. 4 No. 3 (Mar 2017) 220-

235. Dari http://journal.lppmunindra.ac.id/index.php/JABE/article/download/2480/1871

Muchlish Huda, 2018 “Tugas Kepemimpinan Kepala Sekolah Dalam Manajemen Berbasis Sekolah,” al-Afkar, Journal for Islamic Studies 1, no. 2

Mulyasa. E 2012. Manajemen Kepemimpinan Kepala Sekolah. Jakarta: PT Bumi Aksara

Mulyasa. E. 2003. Manajemen Berbasis Sekolah. Bandung: PT. Remaja Rosdakarya

Robbins, P Stephen dan Timothy A Judge, 2015. Perilaku Organisasi, Jakarta: Salemba Empa

Suparlan. 2006. Guru Sebagai Profesi. Yogyakarta : Hikayat.

Suwarto. 2010. Perilaku Keorganisasian. Yogyakarta : Penerbit Universitas Atmajaya 